\title{
Classroom Learning Environments As A Correlate Of Scientific Literacy
}

T. A. Oluwatelure, Adekunle Ajasin University, Nigeria

\begin{abstract}
This study was aimed at investigating the relationship between science learning environments and scientific literacy level of learners. Descriptive research design of the survey type was employed. The population for the study was made up of both secondary school students and science teachers, stratified into types $A, B$, and $C$. Four hundred and forty-nine respondents offering sciences were randomly selected, while 81 respondents were drawn from among science teachers from types $A$, $B$, and C schools. Two self-constructed and validated research instruments - Science Teachers' Questionnaire (STQ) and Literacy Level Rating Scale (LLRS) - were used to collect data for the study. Six research questions and two research hypotheses were raised to guide the study. Results indicated the following: 1) that teachers in the different school types rated their own school learning environments differently, 2) teachers' knowledge about optimum, average and poor learning environments was influenced by the type of school in which they are domiciled, 3) the extent to which teachers made use of locally made materials varied with school type, 4) hindrance to the teaching of science subjects was most serious in type C schools, 5) there is a significant relationship between classroom leaning environments and the respondents' scientific literacy level, and 6) there is a significant difference in the scientific literacy level of respondents based on school types. It is recommended that irrespective of the school type, science teachers ought to be able to develop science learning communities, teacher and student questions, seek information, and validate explanations in various thoughtful creative and cooperative ways. Teachers should shift from design of instruction to design of learning environments.
\end{abstract}

Keywords: Classroom learning environments, Scientific Literacy, Resource for learning

\section{INTRODUCTION}

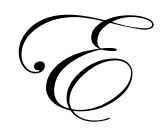

ducators need to be aware of the "ideal" with regard to the type of environment that enhances good learning, and the achievement of good learning outcomes, one of which is scientific literacy. Haertel, Walberg and Haertel (1981) made use of student perceptions of actual classroom environment as prediction variables in several different countries and established consistent relationships between the nature of classroom environment and various student cognitive and affective outcomes. Classroom environment instruments have been used as sources of predictors and criterion variables in a variety of research studies conducted in primary and secondary schools (Fraser, Okebukola and Jegede, 1992; Hofstain, 2004). The study involving 116 Australian science classes established sizable associations between several inquiry skills and science-related attitudes and classroom environment dimensions measured by the classroom environment scale and individualized classroom environment questionnaire.

The Nigerian science classroom of the 80 's exhibited similar characteristics to the classrooms of the 60 's and the 70's. The prevalence of the lecture mode of instructions, close-ended laboratory investigation, and inadequate facilities for group work were reported (Abdulahi, 1982; Ogunniyi, 1985; Okebukola and Ogunniyi, 1984; Okebukola, 1986; Jegede and Fraser, 1989; and Okebukola, 1986) drew attention to the issue of large classes, which worsened the classroom situation in the last decade. It could then be concluded that the preferred classroom environment was lacking. 


\section{LITERATURE REVIEW}

There is the necessity to go into literature in order to see the ideal classroom learning environment. It would also be necessary to determine what literature has on the actual and preferred classroom environments; more so, when the quality of classroom learning environment was linked with achievement of scientific knowledge skills and the achievement of science education goals. Understanding the nature of the learning environment is important for meaningful organization of instruction in science and in STS.

Husen and Postlethwaite (1991) define a learning environment as that which consists of "all those physical sensory elements, such as colour, sound, space, furniture, and so on, which characterize the place in which a student is expected to learn". This surrounding should be designed so that learning may proceed with minimum stress and maximum effectiveness." Thus, a learning environment should promote sensory comfort and high auditory, as well as visual acuity. Its dimension and physical layout should accommodate scheduled activities, allow for people's sense of personal space, and promote desirable patterns of social interaction and communications" (Husen et al, 1991).

In addition to supporting human functioning, the learning environment must accommodate the equipment tools and materials that are used in education and training. The introduction of media, be it chalkboard, computer terminal, video, or film display, inevitably alters the nature of the environment. When media is prudently integrated into the learning environment, it may be effectively employed in ways that are coordinated with basic human sensory processes. Learning environment can be equated with what constitutes the four main themes in teacher individuality. Stubs and Delmont (1977) cited the following as part of the themes:

- $\quad$ Physical setting they create

- Their personal appearance

- $\quad$ Extracts of dialogue from lessons

Lackney (1996) explained "setting" as involving furniture, decorations, physical layout and the background items which supply the scenery and stage. He went further to relate the physical setting to his notion of personal front. These include insignia of office rank, clothing; sex, age characteristics, size and look; posture and the like. Setting does not reveal key elements in the pattern of science subjects.

The relative importance of setting in the explanation of differences in teaching behaviour changes from one group of teachers to another. Science subjects cannot be taught outside the correct setting; that is, laboratory or well laid out classroom with relevant teaching materials already set (Stubb and Delamont, 1977).

"There can be no significant innovation in education that does not have at its centre the attitudes of teachers; and its an illusion to think otherwise. The beliefs and assumptions of teachers, which are the air of a learning environment, determine the quality of the life within it" (Postman and Weingarten; cited by Hardy, and Kirkwood, 1994).

Having looked at various angles of viewing learning environment, we want to examine the difference aspects of the learning environment.

\section{Seating and Desk Design}

Proper seating and desk design are important factors in determining a student's relative comfort and effectiveness as a perceiver, recorder, and possessor of information. Furthermore, there is evidence that improper sitting may result in improper skeletal development in children between the ages of 11 and 16. According to Husen and Postlethwaite (1991), chairs need to accommodate the body dimensions of those who use them; most schools need a variety of chair sizes to serve their student population. In a situation where a single chair has to accommodate varied users, like in fixed work stations such as audio visual/television carrels, video display terminal stations and operational control rooms, freely adjustable chairs are recommended. 
Parts of a chair should consist of the dimensions recommended by Chakrabarti (1997) and NeloferKhanam, Reddy, and Mrunalini (2006).

\section{Seat Pan}

It should be contoured so that an individual's weight is distributed primarily in the buttock area. It should be slightly padded (about an inch) and covered with a porous textured fabric. Seat and frame parts, which come in contact with occupancy body, should be made up of wood or other materials, which are thermally non-conductive.

\section{Backrest}

It should be padded and should provide support in the lower back (lumber region). Chairs that rotate are recommended for large group lecture halls and conference rooms.

\section{Working Surface}

The design of the surface upon which notes are taken, reading, etc., contributes to the individual's operational comfort and effectiveness. A horizontal reading and writing surface forces students to bend forward excessively, causing stress on their skeletal and visual systems, which can cause digestive respiratory, visual, and postural problem.(Palmer, 2005 and Gee, 2006). Proper reading and writing posture is promoted by tilting the whole surface 15 degrees horizontally for note-taking tasks, particularly when viewing informational presentations at the front of the room. Inclining the desktop 30 to 45 degrees places reading and viewing at a comfortable position. Horizontal work surfaces, of course, are best for three-dimensional manipulative tasks. The coordination of seating, viewing and work positions is important to those whose learning activities involve using computer terminals, microfiche readers, or video monitors in a carrel (enclosure).

\section{Room Characteristics}

\section{Room Size and Seating Configuration}

The size of a teaching/learning space should be such that it accommodates the programmed number of occupants and provides additional space for its intended activities. If the intended activities include extensive media use, then additional space should be provided for both the set-up and use of equipment as well as for whatever empty floor space is needed to keep viewers from sitting too close to the display surface (the projection screen) (UNESCO, 1973).

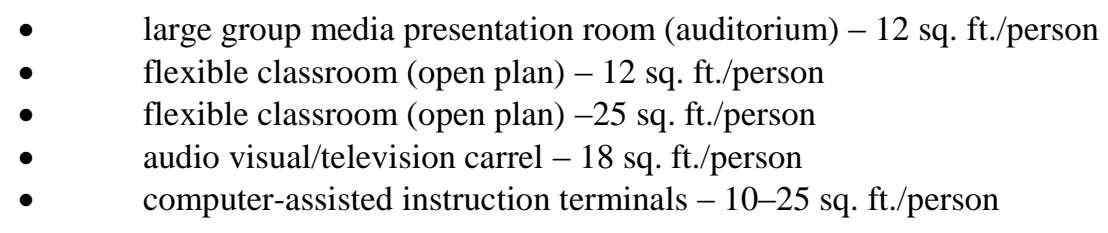

Generally speaking, a $20 \times 32$ foot room will seat about 49 people theatre style, 24 people classroom style, 18 people at a U-shaped table, and 15 people at a conference table. Theatre style seating arrangement is recommended for lecturing, orientation activities and media presentation. A U-shaped seating arrangement also allows for effective media presentation with smaller groups, but promotes more social interaction and discussion. Circular seating pattern promotes more uniform social interaction and discussion. UNESCO (1973) focused on the Nigerian primary school classroom organization and arrangement with particular reference to seating arrangement, distribution and retrieval of materials for effective teaching. Although the science learning environment described by him two decades ago is not the same as it is today, it is important to note that if teaching and learning of science is to be interesting and effective, more emphasis needs to be put on the quality of the environment. He cited the following features of a classroom that is more conducive and meaningful to learning. 


$$
\begin{array}{ll}
- & \text { Water } \\
\text { - } & \text { Science corner } \\
\text { - } & \text { Safety materials } \\
\text { - } & \text { Science charts } \\
\text { - } & \text { Water container } \\
& \text { Equipment table }
\end{array}
$$

In a laboratory setting, he said that the seating arrangement should be such that would allow free movement of both learners and their teachers, as well as laboratory technicians in a teaching learning situation. An important factor identified for dictating the climate of a lesson is availability of materials and equipment for teaching. The more copious the materials and equipment, the higher the number of groups, the smaller the group size, and the need for more options for the seating arrangement. This, of course, results in a better learning environment.

\section{Room Shape}

In a school environment, there are usually different types of accommodation, which are sometimes differently shaped. The classroom and laboratory lecture hall are usually constructed with rectangular corners and length more than twice the width. In very old mission schools, the lecture theatres and conference halls - and sometimes staff common rooms - are of some other shape; i.e. polygonal or dome shaped. All these different shapes are a major factor contributing to overall space aesthetic characteristics, sense of perceptual appropriateness, and the kind of social interaction pattern which its planners desire to promote among its occupants.

\section{Illumination}

Education spaces require lighting that produces a pattern of brightness from room surface, which is aesthetically pleasing and promotes good depth perception. Major and supplementary task areas, such as chalk boards, tack-boards, desks, and other work surfaces, require enough illumination so as to allow students to complete their visual tasks in comfort and with a high degree of visual efficiency.

All sources of illumination must be controlled; i.e. individual switch for fluorescents. Husen and Postlethwaite (1991) recommended the following level of illumination for instructional settings:

- 300-500 lux for general classroom activities

- $\quad 1,000$ lux for critical visual tasks; i.e. artwork, dissecting work on microscope, etc.

- $\quad$-300 lux for audio-visual activities. Classroom chalkboards should have a grid with a reflectance not more than $20 \%$. It may also be some other colour, like grey or black. The floor should be of light colour carpet, tile, or natural wood, etc.

\section{Outdoor Study Area}

Students are generally interested in outdoor study. Teachers are expected to select areas where there are minimum glare, noise, and thermal discomfort. Such trips should not be too long if there are no comfortable facilities. If an outdoor study area is to be of functional value, then the design should include the following features (Cannon and Wilson, 2005):

- Wind break and sound deflecting walls for noise control;

- $\quad$ Tree and shrub plantings for visual privacy;

- $\quad$ Comfortable outdoor seats with a backrest;

- $\quad$ Rotunda for small group work.

It is observed that the physical environment is rich and most relevant to the teaching of interacted science. This physical environment is therefore worth developing by devoting a lion's share of the science vote to it. 


\section{RESOURCE FOR LEARNING}

Jenkins and Whitfield (1974) believed that whatever a teacher seeks to achieve with his pupils, his aspirations will be influenced or - in some instances - limited by the teaching and learning resources available to him. In recent years, the number and range of such resources has increased enormously. This increase is coupled with a greater degree of understanding of the conditions, which makes for effective learning. Advancement in educational technology has stimulated the products of educational aids with great potential for individualization of science instruction, more than we have known in the past Carin and Sund, 1975).

Hardware and software allow teachers to move away from text-centered instruction to communicating with a large number of children and, at the same time, sometimes enabling class members to have a front seat view of objects through image expansion. In other words, maximum learning takes place if the learning environment is enriched by skillful use of media. Learning resources can be grouped as follows:

- $\quad$ Still projection: overhead and opaque, slides and filmstrips

- $\quad$ Movie projection

- $\quad$ Audio taping: phonograph, audiotape recorder

- $\quad$ Multi-media kit

There are also simple visual aids, such as diagrams, illustrations, and graphical representations, which are standard aids for learning. The aids are used in the form of pictures and wall charts or as slide film strips and overhead projector transparencies. They are inexpensive, often simple to use, and above all, clear and impressive in their presentation.

Another aid that influences the learning environment is the worksheet. This term implies a device by which the teacher helps the pupil work as far as possible to his full capacity. It is not supposed to be an instruction sheet only; it also asks questions, which demands thinking. In view of the peculiar nature of worksheets, it designed with a particular class in mind and in relation to specific topics. It is unwise to prepare worksheets too far ahead. It may have a variety of functions as outlined by Jenkins (1974):

- to encourage pupils to think for themselves about the results of their experimental work and to draw conclusions form their observation

- $\quad$ to help the pupils work at their own pace without embarrassment

- $\quad$ to help someone who has been absent to catch up

- to avoid oral repetition of routine instructions and questions

- $\quad$ to help in structuring that form of a record:

- numerical result

○ diagrams and graph work

$\circ$ as a consolidation of logical stages in learning

- $\quad$ to replace or organize written notes

- $\quad$ to provide a piece of semi-programmed learning

It may include instructions on the use of film loops or models and experiments requiring reading and how to carry experiments and discussions.

In most developing countries of the world, today's classroom environment is characterized by large classes, deteriorating classroom buildings, poor lighting and seating conditions, interrupted power supply, insufficient supply of instructional resources/materials, faulty time-tabling, disinterestedness on the part of learners, lack of motivation on the part of teachers, and so on. It makes one wonder if learners are actually experiencing learning that will lead to the kind of understanding of science needed by all citizens, including those who may wish to become scientists. It is therefore necessary to determine the present situation with respect to the learning environment in our schools vis vis the achievement of science education goals. 


\section{PURPOSE OF THE STUDY}

The purpose of this study was to investigate the:

- $\quad$ present situation with respect to the learning environment in our schools

- $\quad$ relationship between classroom learning environment and scientific literacy level of learners with a view to seeing whether an enhanced classroom learning environment will lead to a better scientific literacy level in the recipient of the science curriculum

\section{RESEARCH QUESTIONS}

1. What will be the ratings of science teachers about their own school's learning environments?

2. What impression do teachers have on optimum, average and poor learning environments?

3. To what extent do the teachers make use of locally-made teaching materials in categorized learning environments?

4. What are the teachers' perceptions of their roles during science classes in categorized learning environments?

5. How do the teachers perceive the level of constraints in categorized learning environments to be?

6. Will there be any significant relationship between learning environment and scientific literacy level of respondents?

\section{RESEARCH HYPOTHESES}

1. There will be no significant relationship between learning environment and scientific literacy level of respondents.

2. There will be no significant difference in the scientific literacy of respondents based on their school types.

\section{METHODOLOGY}

\section{Research Design and Sampling Techniques}

Descriptive research design of the survey type was made use of in this study of 449 secondary school students randomly selected from the three school types; 81 science teachers also took part in the study.

\section{Research Instruments}

Two research instruments were made use of in this study; i.e., Science Teacher Questionnaires (STQ) and Literacy Level Rating Scale (LLRS). STQ was designed to elicit responses on the teachers' school learning environments. They were also expected to reveal the extent to which they prepare and use teacher-made apparatus/ materials and how they perceive the extent of seriousness of constraints. LLRS, on the other hand, was designed to measure the scientific literacy acquisition of the respondents. The instruments were separately face-validated by experts in the field of science education and their test-rest reliability yielded 0.6 and 0.75 , respectively.

\section{Data Analysis}

The data obtained were analyzed using descriptive (mean, frequency count and percentages) and inferential (correlation, analyses of variance, and Scheffee) statistical tools.

\section{RESULTS}

The results obtained from this study are as follows: 
Table 1: Teachers' Ratings of Their School Learning Environments in Types A, B, \& C Learning Environments

\begin{tabular}{|c|c|c|c|c|c|c|c|c|c|}
\hline $\begin{array}{l}\text { Categories of Leaning } \\
\text { Environment }\end{array}$ & $\sum \mathbf{X}$ & $\begin{array}{c}\mathrm{A} \\
\text { mean }\end{array}$ & $\mathbf{n}$ & $\sum \mathbf{X}$ & $\begin{array}{c}B \\
\text { mean }\end{array}$ & $\mathbf{n}$ & $\sum \mathbf{X}$ & $\begin{array}{c}\mathrm{C} \\
\text { mean }\end{array}$ & $\mathbf{n}$ \\
\hline $\begin{array}{l}\text { Teachers' knowledge about } \\
\text { optimum, average and poor } \\
\text { LE }\end{array}$ & 95 & 3.5 & 27 & 90 & 3.3 & 27 & & & \\
\hline $\begin{array}{l}\text { Teachers' assessment of } \\
\text { their own school learning } \\
\text { environments }\end{array}$ & 68 & 2.5 & 27 & 40 & 1.5 & 27 & & & \\
\hline $\begin{array}{l}\text { Extent of use of locally- } \\
\text { made materials }\end{array}$ & 43 & 1.60 & 27 & 34 & 1.3 & 27 & 30 & 1.1 & 27 \\
\hline $\begin{array}{l}\text { Teachers' perception of } \\
\text { their role in science } \\
\text { classroom }\end{array}$ & 59.7 & 22 & 27 & 54.0 & 20 & 27 & 46.3 & 17 & 27 \\
\hline $\begin{array}{l}\text { Extent of seriousness of } \\
\text { constraints }\end{array}$ & 41.9 & 15.5 & 27 & 45.7 & 16.9 & 27 & 60.4 & 22.4 & 27 \\
\hline
\end{tabular}

As shown in Table 1, teachers in category A has the best ratings of there learning environments, followed by those in category $\mathrm{B}$, while the poorest ratings came from category $\mathrm{C}$. This pattern of results was observed in the way they made use of locally-made materials. The level of constraint against science learning was most serious in category $\mathrm{C}$.

Table 2: Relationship between the Respondent's Scientific Literacy Level and Learning Environment

\begin{tabular}{|l|c|c|c|c|}
\hline \multicolumn{1}{|c|}{ Variables } & N & Df & r-cal & r-table \\
\cline { 1 - 5 } Scientific literacy & 287 & 285 & $0.388^{* *}$ & 0.111 \\
\cline { 1 - 4 } Learning environments & & & & \\
\hline
\end{tabular}

$0.388>0.111$ table value at 0.05 level of significance; hence, the null hypothesis is rejected.

It should be noted that only the scores of respondents who completed their learning environment checklist appropriately were used in computing the data for Table 2.

Table 3: One-way ANOVA of Scientific Literacy Level of Students in the Categorized Learning Environments (A, B \& C)

\begin{tabular}{|l|c|c|c|c|c|c|}
\hline Sources of Variations & Df & SS & MS & F & P & Critical Value \\
\hline Between groups & 2 & 1949 & 974.5 & \multirow{2}{*}{0.1} & \multirow{2}{*}{0.79} & \\
\hline Within groups & 447 & 47803 & 107 & & & \\
\hline Total & 449 & 49752 & 1081.5 & & & \\
\hline
\end{tabular}

$9.1>4.79$ critical value at 0.5 level of significance; hence, the null hypothesis is rejected.

Table 4: Scheffee Post Analysis Test Result

\begin{tabular}{|l|c|c|c|}
\hline & Categories & Significant & Not Significant \\
\hline FS 12.5 & A,B & $*$ & - \\
\hline FS 0.5 & A,C & - & $*$ \\
\hline FS 17.97 & B,C & $*$ & - \\
\hline
\end{tabular}

\section{DISCUSSION}

In Table 1, it was observed that the science teachers' ratings for type A learning environment was the best for all the items considered. This was followed by type B and C, respectively. The implication of this is that the Old Mission and the Federal government secondary schools have the necessary facilities/equipment and standard physical structures. They also have an adequate information bank as well as experienced teachers, books, computers, pictures, movies, etc. One does not wonder why the ratings of teachers in such schools have high ratings 
of their learning environments. In this research, type B schools were those which were established in the 1970s, many of which were State government owned. This set of schools did not receive as much financial support; hence, there is a short fall in the provision of necessary conditions that support good learning. Type C schools consisted of those schools that were established in the late 1980s when schooling by citizens and establishment of schools became part of the political campaign; i.e. the free and compulsory education syndrome. Qualitative education gave way to quantitative education. Teachers in this type of school saw their environments as bare and having nothing to offer either teachers or learners; i.e insufficient seats, ill-equipped laboratories, no supply of electricity, and so on. This situation was most prominent in community schools and constraints to effective teaching and learning of science was most serious. This is typical in Nigeria and most developing countries. In most countries of the world, education is a fundamental human right for all citizens and is supported by all levels of government. The difference observed among the three strata of students and staff population is uncalled for. Government, whether military or democratic, should accompany free and compulsory education with provision of a setting or educational space wherein the learners act using tools and devices to collect and interpret information. In order to achieve national educational goals, one of which is scientific literacy, the government needs to pay attention to not only learners and the physical settings, but also to the third, and most important, component of the learning environment - the teachers, in terms of effective and comprehensive teacher preparation scheme.

In Table 2 where the results of the hypothesis testing were displayed, it was observed that correlation of the respondents' scientific literacy level scores, along with their corresponding learning environment checklist scores, was significant. This confirms a strong relationship between scientific literacy level scores of the respondents and their learning environment checklist scores. It may also imply that the two variables - science learning goals and science learning environments - are influenced by common factors.

In Table 3 where the results of the second hypothesis testing was displayed, it could be observed that there was a significant difference in the scientific literacy level of the respondents based on their science learning environment, leading to the rejection of the null hypothesis raised. On the application of the Scheffee procedure to compare the various learning categories pair-wise, it was discovered that when learning categories A and B were compared (FS of 12.5 was greater than the F' prime of 9.58), there was a significant difference. When this same procedure was applied to categories B and C, there was also a significant difference (FS > F). This observation may probably be attributed to the fact that science teachers put much emphasis on the design of science instruction rather than on design of science learning environments. Most of the teachers are able to design what is to be learned, but fail to plan an intervention that will allow the learning to occur. Jonassen (1994) suggests a constructivist approach where less emphasis is placed on the sequence of instruction and more emphasis is placed on design of the learning environment. Another reason for the great difference in the learning outcome (scientific literacy) of the respondents in categorized environments is that teachers fail to search for science material and teaching strategies that will cater for diverse abilities, interests and backgrounds. They sometimes do not use available time, materials, equipment and communications in supporting students' scientific investigations. They may also be unaware of the "notion of learning environments in the context of instructional design". Teachers must be aware of the importance of all components of the learning environment and distinguish them from ultimate constructivist learning environments. According to Wilson (1996), constructivist learning environment is a place where learners may work together and support each other as they use a variety of tools and information resources in their guided pursuit of learning goals and problem-solving activities. Science teachers, irrespective of their school type, must realize that the task of science learning is a joint responsibility of both students and teachers; hence, the "the teacher tell" strategy, which is most patronized by young and inexperienced teachers, should be discouraged.

\section{CONCLUSION}

There is a pointer to the future. All stakeholders in education need to look forward to the improvement upon the past and learning environments with a view of creating a constructivist learning environment where students are able to control their own learning. 


\section{RECOMMENDATION}

In this information age in which the whole world has become a global village, acquisition of scientific literacy for citizenship is recommended, but as a tool for global unity.

\section{AUTHOR INFORMATION}

T. A. Oluwatelure is a lecturer in the department of science and technical education, Adekunle Ajasin University, one of the State government universities in the country. She taught integrated science courses and science method courses in the department where she currently works and at the College of Education, Ikere Ekiti Ekiti State, where she had earlier worked for twelve and a half years. She is responsibly married with four children. As a coordinator for all levels of the integrated science students in the department, she is actively involved in monitoring, mentoring, counseling and preparing undergraduates for their future.

\section{REFERENCES}

1. Abdulahi, A ,(1982). Science Teaching in Nigeria. Ilorin: Atoto Press.

2. Carin. A. A. \& Sund, R. B. (1975): Teaching Science through Discovery. Ohio. America Charles E. Merrill publishing Co.

3. Chakrabarti, D. and Hum, J.E (1997) Indian Anthropometric Dimensions. National Institute of Design Publishers. Arhmedabad. Pp 96-101, 123-129.

4. Fraser, B. J., Okobukola, P. A., Jegede, O. J (1992). Assessment of learning Environment of Nigerian science laboratory classes Journal of STAN. 27, (2) 1 - 17.

5. Gee, L. (2006) Human-centered Design Guideline. In D. Oblinger (Ed) Learning Space. An Educause ebook. On-line Url http//www.educause.edu/book/learning space/10569.

6. Haertel, G. D., Walberg, H.J., Haertel, E.H. (1981). Socio-Psychological environments and learning: A quantitative syncthem. British Educational Research Journal. 7, 27 - 36.

7. Hardy, T.and Kirkwood,V. (1994) Towards creating effective learning environment for science teachers. The role of science educators in the tertiary setting. International Journal of science education. 16,(2),231251.

8. Hofstein, A. (2004) Chemistry Education Research and Practice. Contributions of Educational Research to the practice of Chemistry Education. Laboratory and practical work 5, (3) 247-264.

9. Husen. T \& Postlethwaite. T.N (Eds). The international encyclopedia of Education. Volume 9, $2^{\text {nd }}$ edition. 5345-5350.Oxford, U K. Pergamon press.

10. Jegede, O.J. and Fraser, B (1989). Influence of socio- cultural factors towards science. Researches in Education. 19, $155-163$.

11. Jenkins. E. W. (1994) Scientific literacy. In Husen. T \& T.N. Postlethwaite (Eds). The international encyclopedia of Education. Volume 9, $2^{\text {nd }}$ edition. 5345-5350.Oxford, U K. Pergamon Press.

12. Jonassen, D.H., (1994) Thinking Technology. Towards a constructivist design model. Education Technology, 34(3), 34-37.

13. Lackney, J.A (1996) Quality in school environments. A multiple case study of elementary schools in the Baltimore City Public Schools from an action research perspective. School of Agriculture and urban planning. University of Wisconsin-Milwaukee. UMI Dissertation services. No 9717142.

14. NeloferKhanami, C, Reddy M.V., Mrunalini A, (2006) Designing students seating furniture for classroom environment. Kamplan Raj. J. Hum. Ecol. 20(4)241-248.

15. Ogunniyi, M. B. (1985) Science Teaching in Africa. Ibadan: Salem Media.

16. Ogunniyi, M. B. (1985) Science Teaching in Africa. Ibadan. Salem Media.

17. Okebukola, P A. O. and Ogunnniyi, M. B. (1984). Cooperative, Competitive and individualistic Science laboratory interaction patterns: Effects on students' achievement and acquisition of practical skills. Journal of Research in science Teaching .21(9), $875-884$.

18. Palmer, C. (2005) Educating learners with vision impairment in inclusive setting. International Congress Series. Vol. 1282, 922-926.

19. Sttubbs and Delamont, S. (1977) Exploration in classroom observation. New York. John Wiley and Sons.

20. UNESCO (1973) Source book for teaching science. 
21. Wilson,B.G. Ed. (1996) Constructivist learning environments: Case study in Instructional Design. Educational Technology Publications. Eaglewood Cliffs NJ.

22. Wilson, K. (2005) Outdoor classroom. Kathy Wilson Foundation.

\section{NOTES}

